\title{
KOLEKSI MEBEL ANTIK MUSEUM SEJARAH JAKARTA
}

\author{
Amarena Nediari \\ Jurusan Desain Interior, Fakultas Komunikasi dan Multimedia, Bina Nusantara University \\ Jln. K. H. Syahdan No.9, Palmerah, Jakarta Barat 11480 \\ anediari@binus.edu
}

\begin{abstract}
Collection of antique furniture is the most dominant type collection belongs to the Jakarta History Museum. The museum building is located in tourist areas Kotatua Jakarta, which became the center of historic and cultural development of the city. The purpose of this research is to determine the condition of furniture in the museum's collections so that the rescue of cultural heritage and history associated with the city through the exhibition can be done well. Methods of research conducted by collecting data from various literature sources, surveys and interviews with the management of Jakarta History Museum as a resource. Unfortunately, the furniture collection is currently not maintained and not well protected so that the high historical value of cultural heritage and history of the city of Jakarta is almost negligible. Conclusion from this research is to realign of the furniture collection at the Museum of History of Jakarta.
\end{abstract}

Keywords: antique furniture, museum, Kotatua Jakarta, historical value

\begin{abstract}
ABSTRAK
Koleksi mebel antik merupakan jenis koleksi yang paling dominan dimiliki oleh Museum Sejarah Jakarta. Bangunan museum berada di kawasan wisata Kotatua Jakarta, yang menjadi pusat dari sejarah dan perkembangan budaya kota Jakarta. Tujuan dari dilakukannya penelitian adalah untuk mengetahui kondisi koleksi mebel di dalam museum sehingga penyelamatan warisan sejarah dan budaya yang berkaitan dengan kota Jakarta melalui pameran dapat dilakukan dengan baik. Metode penelitian dilakukan melalui pengumpulan data dari berbagai sumber literatur, survei ke lokasi dan wawancara dengan pihak manajemen Museum Sejarah Jakarta sebagai narasumber. Sangat disayangkan, saat ini koleksi mebel sangat tidak terawat dan tidak terlindung dengan baik sehingga nilai historis yang tinggi dari peninggalan budaya dan sejarah kota Jakarta nyaris terabaikan. Simpulan dari penelitian ini yaitu perlu dilakukan penataan kembali terhadap koleksi mebel di Museum Sejarah Jakarta.
\end{abstract}

Kata kunci: mebel antik, museum, Kotatua Jakarta, nilai historis 


\section{PENDAHULUAN}

Museum Sejarah Jakarta, yang berlokasi di Jalan Taman Fatahillah Nomor 2, Jakarta Barat, adalah pusat dari kawasan wisata Kotatua Jakarta. Museum yang juga dikenal dengan nama Museum Fatahillah ini memiliki berbagai koleksi yang berkaitan dengan perkembangan sejarah dan budaya kota Batavia sampai menjadi kota Jakarta. Bangunan peninggalan kolonial Belanda bergaya baroque klasik ini mempunyai luas kurang lebih $1.300 \mathrm{~m} 2$ dan terdiri atas dua lantai. Dibangun pada tahun 1707 oleh oleh Gubernur Jenderal Joan Van Hoorn dan diresmikan pada tahun 1710 oleh Gubernur Jenderal Abraham van Riebeeck. Pada awalnya bangunan megah ini berfungsi sebagai kantor Balaikota (Stadhuis), yang merupakan pusat dari kegiatan Dewan Kota Praja (College van Scheepnen) dan Dewan Pengadilan (Raad van Justitie) selain itu Balaikota juga digunakan sebagai panitia kesejahteraan anak yatim piatu, catatan sipil, ruang beribadah sementara (1622-1640) dan sebagai pemakaman Jan Pieterszoen Coen (1587-1619) sebelum jenazah dipindahkan ke gereja (sekarang adalah Museum Wayang).

Pengalihan fungsi Balaikota menjadi Museum Sejarah Jakarta diresmikan oleh Gubernur DKI Jakarta, Bapak Ali Sadikin pada 30 Maret 1974 dan termasuk dalam Kawasan Cagar Budaya Kotatua berdasarkan Peraturan Gubernur Provinsi DKI Jakarta no.34/2005. Benda koleksi Museum dapat merupakan benda asli (realia) maupun benda tidak asli (replika). Berbagai mebel dari abad ke-17 dan ke-18 yang menjadi koleksi Museum Fatahillah merupakan benda-benda asli yang berhubungan dengan sejarah Ibukota Jakarta. Koleksi ini mulai dikumpulkan oleh Bataviaaasch Genootschap van Kunsten en Wetenschappen yaitu Perkumpulan Batavia untuk kesenian dan ilmu yang didirikan tahun 1778. Terdapat banyak barang berharga hilang setelah Perang Dunia II (masa kedudukan Jepang di Indonesia). Semula benda-benda koleksi ini disimpan di Museum Nasional, Medan Merdeka namun sebagian besar dipindahkan ke Balaikota (Stadhuis) menjelang diresmikan menjadi Museum Sejarah Jakarta pada tahun 1974.

Mengacu kepada hasil musyawarah umum ke-11 (11th General Assembly International Council of Museum [ICOM]) pada tanggal 14 Juni 1974 di Denmark, dikemukakan bahwa fungsi museum adalah pengumpulan dan pengamanan warisan alam dan budaya, dokumentasi dan penelitian ilmiah, konservasi dan preservasi, penyebaran dan pemerataan ilmu untuk umum, pengenalan dan penghayatan kesenian, pengenalan kebudayaan antar daerah dan antar bangsa, visualisasi warisan alam dan budaya, cermin pertumbuhan peradaban umat manusia, pembangkit rasa takwa dan bersyukur kepada Tuhan Yang Maha Esa. Selain itu, museum dalam kaitannya dengan warisan budaya adalah lembaga, tempat penyimpanan, perawatan, pengamanan, dan pemanfaatan benda-benda bukti materiil hasil budaya manusia serta alam dan lingkungannya guna menunjang upaya perlindungan dan pelestarian kekayaan budaya bangsa (Pasal 1.(1).PP. No. 19 Tahun 1995).

Koleksi merupakan sesuatu yang dikumpulkan, dapat berarti sebuah tindakan ataupun pengumpulan, dimana sekelompok objek ini harus dilihat dan dipelajari, ataupun kumpulan benda yang berkaitan dengan cabang kesenian, disiplin ilmu, ilmu pengetahuan dan teknologi. Pengadaan koleksi dapat dilakukan dengan cara hibah (hadiah atau sumbangan), titipan, pinjaman, tukar menukar dengan museum lain, hasil temuan (dari hasil survei, ekskavasi, atau sitaan, imbalan jasa (pembelian dari hasil penemuan atau warisan). Beberapa prinsip dan persyaratah sebuah benda dapat dijadikan koleksi adalah memiliki nilai sejarah dan nilai ilmiah (termasuk nilai estetika), dapat diidentifikasikan mengenai bentuk, tipe, gaya, fungsi, makna, asal secara historis dan geografis, genus (untuk biologis), atau periodenya (dalam geologi, khususnya untuk benda alam), harus dapat dijadikan dokumen, dalam arti sebagai bukti kenyataan dan eksistensinya bagi penelitian ilmiah. Koleksi mebel merupakan jenis koleksi yang paling dominan di Museum Sejarah Jakarta, baik secara jumlah maupun besarannya. Sehingga perlu dilakukan penelitian mengenai koleksi mebel yang sesuai dengan kemampuan museum dalam melakukan perawatan. 


\section{METODE PENELITIAN}

Penelitian ini dilakukan melalui pengumpulan data dari berbagai sumber literatur tercetak maupun elektronik, survei ke lokasi dan wawancara yang dilakukan dengan pihak manajemen Museum Sejarah Jakarta sebagai narasumber.

\section{HASIL DAN PEMBAHASAN}

Dalam perkembangannya Museum Sejarah Jakarta tidak hanya sebagai tempat untuk merawat dan memamerkan peninggalan periode Batavia, tetapi juga menjadi tempat yang informatif dan rekreatif bagi pengunjung museum. Pengunjung museum terdiri atas umum, anak-anak dan ilmuwan. Melalui tata pamernya Museum Fatahillah berusaha menggambarkan Jakarta sebagai pusat pertemuan budaya dari berbagai kelompok suku baik dari dalam maupun dari luar Indonesia dan sejarah kota Jakarta seutuhnya.

Pada 13 April 2010, Museum Fatahillah menggelar film dengan dinding depan museum difungsikan sebagai layar, sebuah pertunjukkan seni video mapping 3D ini pertama kali digelar di Indonesia sebagai hasil kolaborasi seniman multimedia Inggris D-Fuse dengan sineas muda Sakti Parantean dan Adi Panuntun, fotografer Feri Latief dan penulis Taqarrable. Pertunjukan ini difasilitasi oleh oleh British Council Indonesia, Pemerintah Provinsi DKI Jakarta, dan Kamar Dagang Indonesia. Hal ini membuktikan bahwa sampai saat ini Museum Fatahillah masih menjadi pusat dari kegiatan budaya di Jakarta.

Selain koleksi mebel antik dari abad ke-18 masih terdapat benda yang menjadi koleksi Museum Fatahillah, benda-benda yang berhubungan dengan sejarah Ibukota Jakarta yaitu artefak Hindu, Budha dan Islam, kebudayaan Betawi, gerabah, keramik, prasasti-prasasti, koin-koin, meriam, peta-peta kuno, bendera era Fatahillah , lukisan Raden Saleh dan foto-foto Jan Pieterszoen Coen. Koleksi objek arkeologi, historika dan seni rupa merupakan sebagian besar dari koleksi yang dimiliki oleh Museum Fatahillah dan mebel antik merupakan jenis koleksi historika yang membutuhkan penempatan, pengamanan, perlidungan dan penyediaan tempat yang baik untuk menjaga warisan budaya manusia dalam sejarah perkembangan kota Jakarta. Penataan benda koleksi dilakukan berdasarkan kronologis sejarah yang juga didukung oleh foto-foto, gambar, sketsa, peta dan label.

\section{Koleksi Mebel Antik}

Koleksi mebel di Museum Fatahillah tidak semuanya digunakan pada masa kedudukan Belanda di Stadhuis Batavia (sebutan Jakarta di masa itu), namun koleksi mebel tersebut merupakan mebel yang dimiliki oleh orang-orang kaya di Batavia pada abad ke-17. Pada masa sebelumnya, hanya raja dan bangsawan saja yang dapat duduk di kursi, namun di abad ke-17 ini bangku panjang dan mebel lainnya sudah digunakan oleh masyarakat tinggi dan menengah.

Koleksi mebel dalam Museum Fatahillah ini dikumpulkan oleh Dr. L. Serrurier, V.I. van de Wall dan Dr. Th. Van der Hoop untuk Bataviaasch Genotschap sejak tahun 1896. Pada tahun 1950 koleksi mebel dan perabot masa Nederlands-Indie adalah koleksi yang paling lengkap dan berharga. Koleksi mebel antik di Museum Fatahillah merupakan mebel-mebel yang berasal dari abad ke-17 dan ke-18, dengan mutu serta gaya yang berbeda, jumlah yang dipamerkan mencapai sekitar 150 unit. Mebel ini digunakan pada gedung umum maupun dalam rumah-rumah pribadi, umumnya terbuat dari kayu hitam dan kaliatur dengan pahatan-pahatan khas dari masanya. 
Desain mebel antik secara keseluruhan masih mengacu pada gaya Eropa dengan pengaruh dekorasi motif India dan Indonesia. Diproduksi di Batavia dan Kolombo (Srilanka) oleh budak Tamil dan Bengali dan diimpor oleh orang Belanda, namun ada juga yang memang khusus diimpor dari Maluku. Ekspor ke Eropa sudah dilakukan sejak abad ke-17. Tukang perabot (pembuat mebel) ini merupakan budak yang sangat mahal karena pandai. Perkembangan mebel antik di Batavia terlihat pada tahun 1680-1720 yaitu mulai dikenal corak baru berupa pahatan yang lebih dalam, yang dikenal sebagai setengah relief dan di akhir abad 17, pengrajin dari Sulawesi, Bali dan Cina mengambil alih usaha mebel ini. Pada masa ini budak-budak India banyak yang menikahi orang Indonesia dan Indo Eropa, sehingga hilanglah mereka secara kelompok terpisah.

\section{Bangku panjang (Long chair)}

Berbagai koleksi bangku panjang dipamerkan di lantai dasar dan lantai atas museum. Bangku dengan panjang mencapai 150-180 cm digunakan sebagai tempat duduk dan bersantai. Desainnya sangat beragam, namun umumnya menggunakan material kayu jati pada abad ke-19. Gambar 1 merupakan koleksi bangku panjang yang dipamerkan di museum. Detail ukiran pada sandaran tangan berbentuk singa, merupakan pengaruh budaya cina yang masuk ke Indonesia, sementara pada bangku berikutnya detail kayu berulir pada penguat bangku bagian bawah merupakan ciri khas dari mebel gaya Maluku, dan pada bangku lainnya penggunaan anyaman rotan pada bagian dudukan dan sandaran bangku serta detail ukiran floral khas Indonesia sudah dipadukan dengan detail garis merah yang merupakan pengaruh budaya Cina.
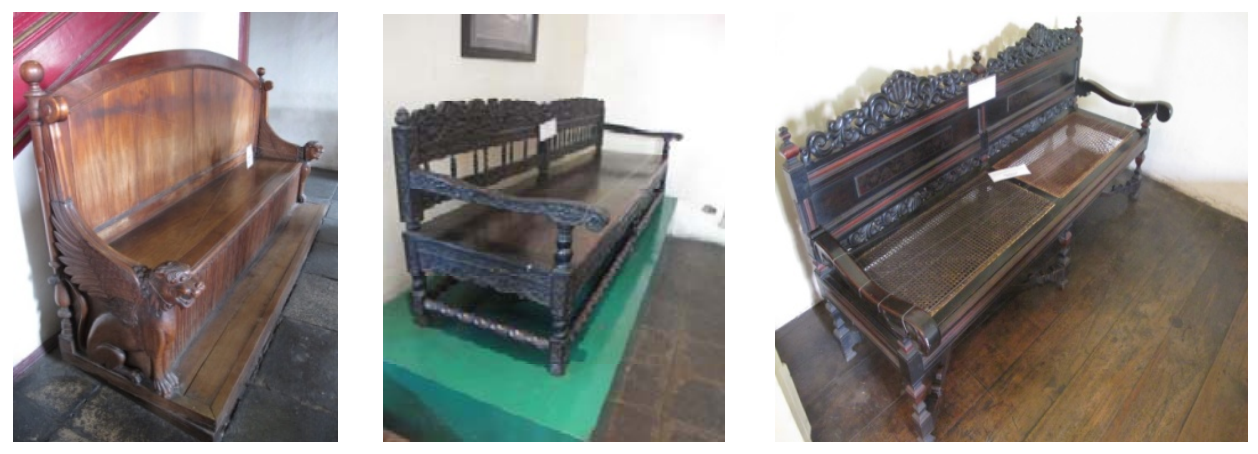

Gambar 1 Koleksi bangku panjang

\section{Lemari Berkaki (Cabinet on Stand)}

Beragam koleksi lemari berkaki terdiri atas gaya pantai Coromandel, gaya Empire dan Baroque Belanda. Lemari berkaki ini umumnya mempunyai ukuran 120x60x140 cm, berfungsi sebagai tempat penyimpanan buku, piring, alat rumah tangga sampai dengan botol anggur. Lemari berkaki dengan gaya pantai Coromandel terbuat dari kayu kaliatur dan diproduksi pada perioede 16501680. Detail yang menarik dari pintu lemari adalah pahatan dangkal motif daun dan pucuk bunga besar yang disusun indah, merupakan pengaruh Arab, selain itu terdapat gambar tentara yang berbeda kepangkatan, kuda dan meriam namun kepala tentara ini dihilangkan kemudian. Lemari berkaki bergaya Empire terbuat dari kayu jati pada abad ke-18, laci pada bagian bawah digunakan untuk menyimpan barang-barang yang berharga. Lemari berkaki bergaya Baroque Belanda (Dutch Baroque) digunakan untuk menyimpan perlengkapan tempat tidur, bagian tepi lemari dipahat dengan motif bidadari, daun dan bunga yang merupakan corak yang sangat terkenal di Belanda, namun tidak di Batavia, diproduksi pada periode 1665-1700 dari kayu Ambon hitam. Di dalam katalog menerangkan koleksi mebel antik Museum Sejarah Jakarta, lemari ini mempunyai pintu yang sedang diperbaiki, namun hingga saat ini lemari masih dalam kondisi tidak berpintu. 


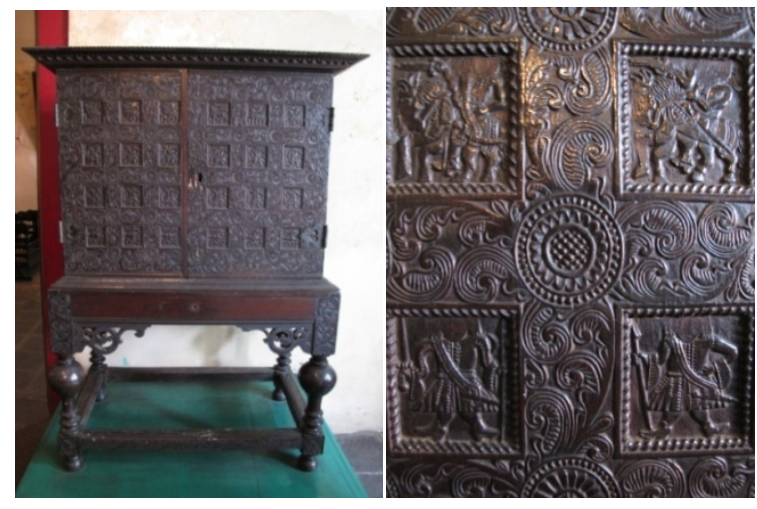

Gambar 2 Lemari Berkaki Gaya Pantai Coromandel
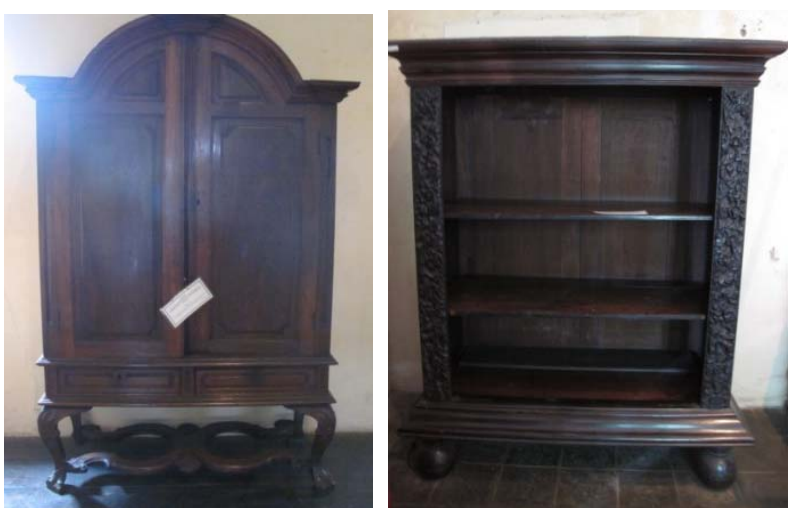

Gambar 3 Lemari Berkaki Gaya Empire dan Dutch Baroque

\section{Ayunan (Cradle)}

Ayunan ini merupakan tempat tidur bayi dengan tiang-tiang kecil pada ujungnya yang berfungsi sebagai tempat menggantungnya kain kelambu untuk melindungi bayi dari gigitan nyamuk yang hidup di negara tropis. Hal yang sangat menarik adalah ayunan ini sangat popular di di Pesisir Koromandel (India Tenggara) pada periode 1650-1680, namun detail ukiran motif bunga menunjukkan bahwa kemungkinan ayunan ini di produksi di Indonesia. Ayunan lainnya mempunyai bentuk yang hampir sama namun detail ulir kayu pada tiang dan pinggiran ayunan merupakan ciri khas dari gaya mebel Maluku.

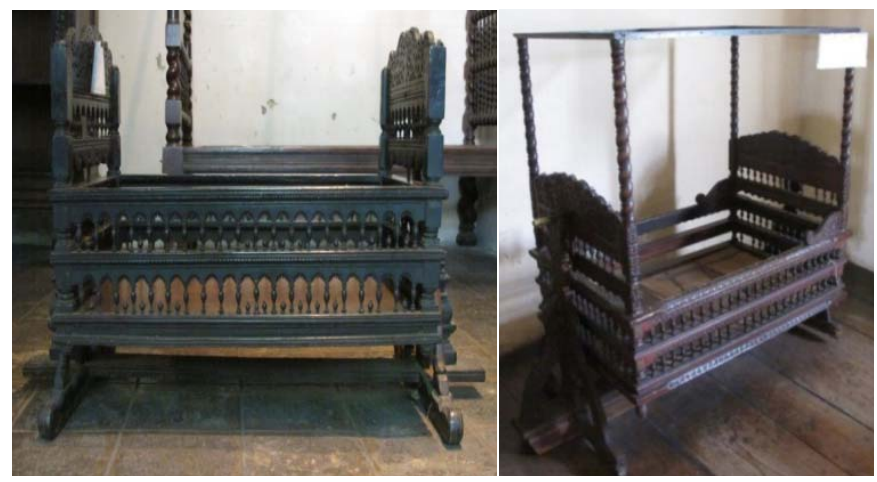

Gambar 4 Ayunan Gaya Pantai Coromandel dan Maluku 


\section{Lemari Buku Besar (Schepenkast)}

Lemari dengan dimensi 240x60x400 cm ini terbuat dari kayu jati dengan detail ukiran kayu yang disepuh prada (emas) pada bagian topi (atas) dan sisi lemari. Ditempatkan di Ruang Dewan Pengadilan, lemari ini diproduksi pada tahun 1748 untuk Dewan Pengadilan (Raad van Justitie) yang awalnya berkantor di kasteel Batavia (Benteng Batavia) dan kemudian pindah ke ruang ini. Pada 23 Maret 1747, Dewan membicarakan keadaan mereka yang tidak mempunyai tempat arsip dan perpustakaan dan pada rapat selanjutnya 1 Juni 1747 mereka memutuskan untuk memesan lemari buku baru. Pada tahun 1871 lemari buku ini diserahkan kepada Bataviaasch Genootschap (Lembaga Kebudayaan Indonesia) karena mebel ini memiliki nilai historis dalam perkembangan budaya kota Jakarta.

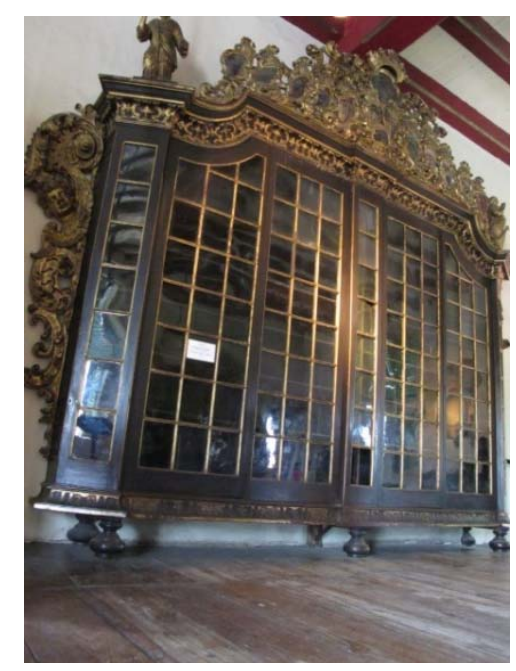

Gambar 5 Lemari Buku Besar(Schepenkast) dari Abad 18

Detail yang menarik pada lemari ini ada pada bagian topi lemari, yaitu di sebelah kiri terdapat patung Dewi Keadilan, yang dahulu tangan kanan membawa pedang keadilan dan tangan kiri membawa timbangan. Di sebelah kanan patung Dewi Kebenaran, dahulu tangan kanan membawa cermin dan tangan kiri mencekik seekor ular. Namun sekarang atribut ini tidak ada lagi. Diantara kedua patung tersebut terdapat ukiran yang menggambarkan 14 (empat belas) lambang keluarga dari anggota Dewan Pengadilan, termasuk pada bagian puncak adalah lambang keluarga Presiden Reiner Stapel.

Hingga saat ini lemari buku besar ini masih terlihat megah, namun beberapa kaca pada pintu banyak yang sudah lepas dan debu yang menempel membuat lemari buku besar ini tidak dalam kondisi terawat dengan baik.

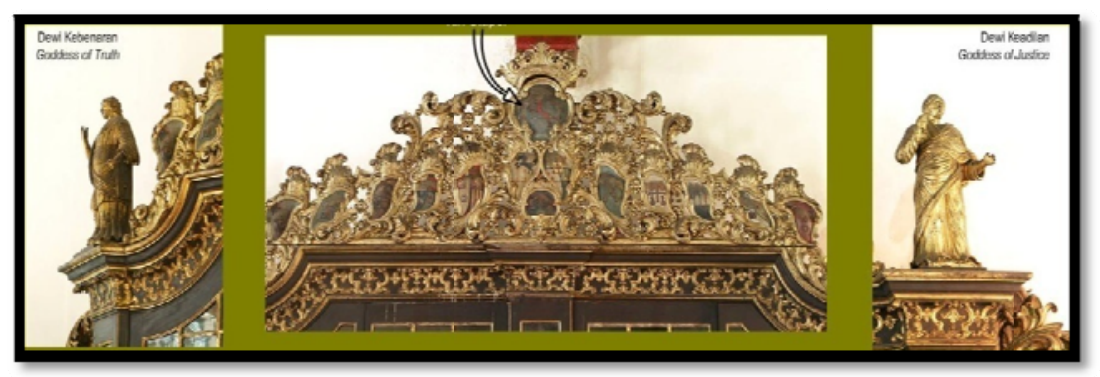

Gambar 6 Detail ukiran prada pada bagian atas lemari buku/Schepenkast 


\section{Partisi Berukir (Room Devider/ Screen)}

Penyekat ruangan (schutsel) ini berada di ruang Dewan Pengadilan, berukuran 289 x $232 \mathrm{~cm}$, bergaya Baroque dan dibuat di abad ke-18, berbahan kayu keras dengan finishing cat merah dan sepuh emas (prada) pada detail ukiran. Penyekat ini pernah digunakan di dalam ruang sidang Dewan Hindia di Benteng (Kasteel Batavia).

Figur pada bagian tengah partisi menggambarkan seorang pria muda memakan baju zirah dengan kaki yang agak pendek, membawa perisai dengan bentuk hiasan kepala Medusa dari Dewi Pallas Athena (Dewi Kebijaksanaan). Dalam mitos Yunani, Pallas Athena (Putri Dewa Zeus) lahir dengan memakai baju zirah dan dianggap sebagai Dewi Kebijaksanaan dan Kesenian.

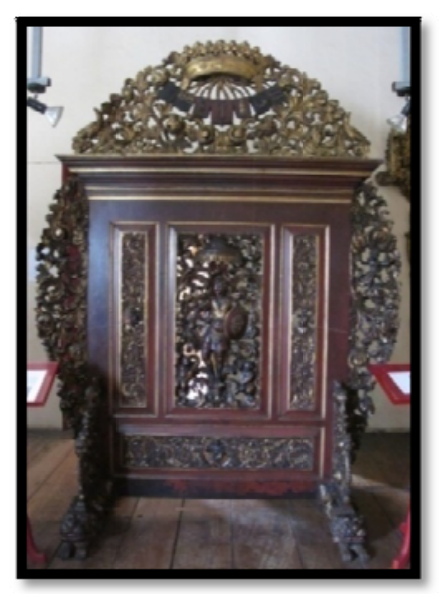

Gambar 7 Partisi berukir dari abad ke-18

Pada bagian atas, di bawah mahkota terdapat 7 lambang kota yang membentuk VOC (Verenigde Oostindische Compagnie) yaitu Delft, Rotterdam, Amsterdam, Batavia, Middleburg, Hoorn, dan Enkhuizen. Posisi lambang kota Batavia berada tepat di tengah, yaitu pedang dengan ujung menembus lingkaran daun salam, hal ini menunjukkan bahwa partisi berukir ini khusus diproduksi untuk ditempatkan di Batavia.

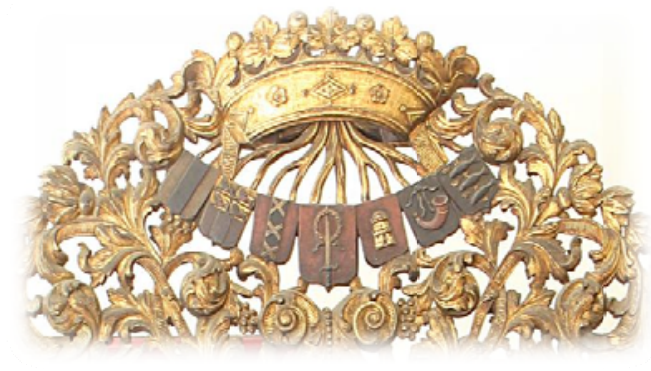

Gambar 8 Ukiran lambang dari 7 kota pembentuk VOC

Peletakan partisi ini cukup menarik perhatian pengunjung, karena keberadaan lampu sorot telah menempatkan koleksi mebel partisi ini istimewa, namun sepertinya perlindungan terhadap koleksi perlu lebih diperhatikan agar kondisi dari koleksi mebel Museum Fatahillah ini dapat terus terjaga dengan baik. 


\section{Meja Sidang Oval (Oval Table)}

Meja Sidang Oval berada di ruang Dewan Pengadilan, mempunyai dimensi 240x140x75 cm yang terbuat dari kayu jati solid pada abad ke-17. Meja berbentuk oval ini berfungsi sebagai meja sidang bagi para Dewan Hindia (semacam kabinet) beserta para Gubernur Jenderal memutuskan nasib jutaan orang berkaitan dengan politik Kumpeni di seluruh Asia. Meja sidang ini mempunyai perpaduan kaki baluster (1600-1645) dan ujung kaki platte bolvoet (1680-1710). Detail tanpa sambungan pada permukaan meja merupakan sebuah desain menarik yang menampilkan kekayaan bumi Indonesia akan kayu jati yang terkenal dengan seratnya yang indah.

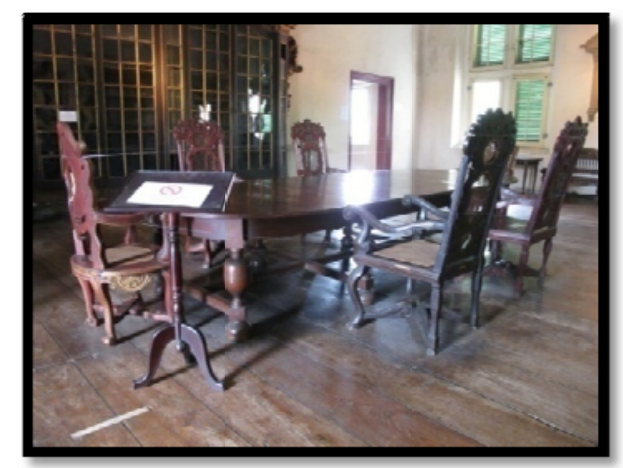

Gambar 9 Meja Sidang Oval dari abad 17

\section{Kursi Sidang Bertangan (Arm Chair)}

Kursi bergaya Baroque ini diproduksi pada abad ke-18 dengan material kayu jati dengan finishing coklat kemerahan.Kursi yang terdiri atas 6 unit ini diletakkan mengelilingi bentuk meja sidang yang oval. Sandaran tangan yang terdapat pada seluruh kursi memberikan arti bahwa seluruh peserta yang duduk di meja tersebut mempunyai kedudukan yang sama. Sandaran punggung dan bagian dudukan kursi menggunakan perpaduan kayu dan anyaman rotan, dipengaruhi oleh gaya Chippendale lintrug (1754) serta kaki depan bergaya Cabriole (1750-1775) sementara kaki belakang bergaya Recht geprofileerd (1750-1775) sehingga diperkirakan Kursi Sidang bertangan ini dibuat pada abad ke-18.

Kondisi koleksi kursi sidang bertangan ini sangat membutuhkan perawatan, dimana sandaran anyaman rotan terlihat sudah rusak, dan keberadaan benang transparan sebagai pelindung terlihat mengurangi keanggunan dan kemegahan dari koleksi mebel yang memiliki nilai historis yang tak ternilai.
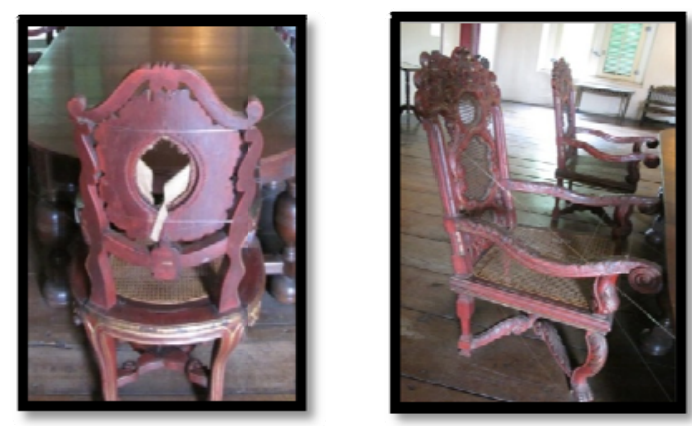

Gambar 10 Kursi Sidang bertangan dari abad ke-18 


\section{Kondisi Mebel Antik}

Pengaruh gaya Eropa yang sangat kental dan perpaduan dengan gaya timur terlihat pada dimensi mebel yang berukuran besar, bentuk kaki yang bulat dan detail ukiran bunga pada mebel. Hal ini terjadi karena pada proses pengerjaannya mebel Eropa digunakan sebagai contoh sementara detail ukiran sudah dikerjakan oleh budak setempat.

Koleksi mebel antik di Museum Fatahillah merupakan koleksi asli dan bukan replika dengan nilai historis yang tidak ternilai, koleksi mebel yang telah berusia 300 tahun ini dapat bercerita mengenai sejarah perkembangan gaya mebel di abad ke-17 dan perannya dalam sejarah berdirinya kota Jakarta, sehingga perlindungan dan perawatan koleksi mebel perlu lebih diperhatikan. Hal ini tentu dapat dilakukan dengan melakukan perawatan, penataan ulang sampai dengan rotasi koleksi.
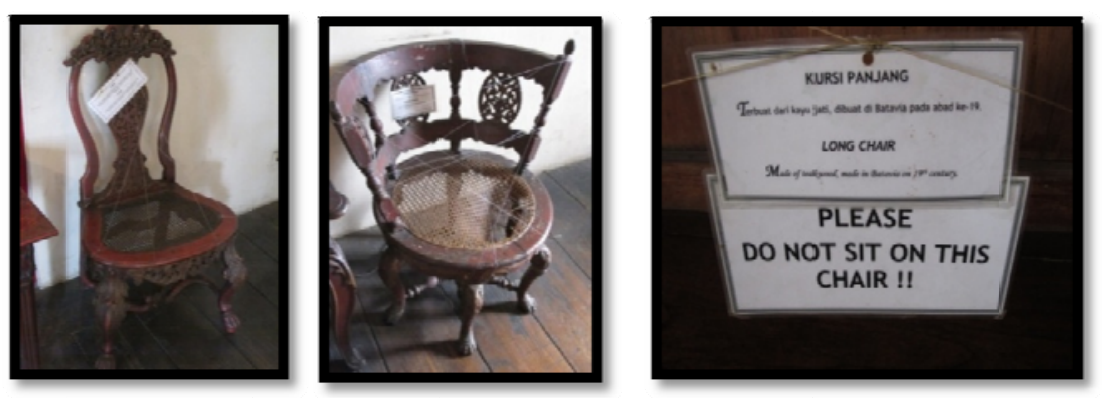

Gambar 11 Kondisi mebel antik dan informasi koleksi

Informasi mengenai sejarah koleksi mebel (labelling) sebenarnya sudah memadai, tapi belum diterapkan secara menyeluruh pada tiap koleksi mebel. Perlindungan terhadap kondisi label juga perlu dipertimbangkan, mengingat pengunjung museum ini berasal dari berbagai tingkat sosial dan usia yang berbeda dimana perilaku dalam menikmati dan menghargai koleksi juga masih sangat beragam, ada yang memegang, cukup dengan melihat, meraba atau bahkan kadang mengetuk, dan masih dijumpai untuk koleksi mebel kursi kondisinya dapat semakin rusak karena perilaku pengunjung yang ingin mencoba duduk di atas koleksi kursi.

Penggunaan panggung setinggi $20 \mathrm{~cm}$ berwarna hijau sebagai sarana display dimaksudkan untuk menjaga kondisi koleksi agar tidak mudah diduduki, namun warna yang terang mengakibatkan perhatian beralih pada warna panggung bukan pada koleksi mebel. Selain itu, penggunaan panggung ini belum diterapkan pada seluruh koleksi, sehingga tidak semua pengunjung dapat memahami panggung sebagai salah satu upaya perlindungan terhadap koleksi mebel.
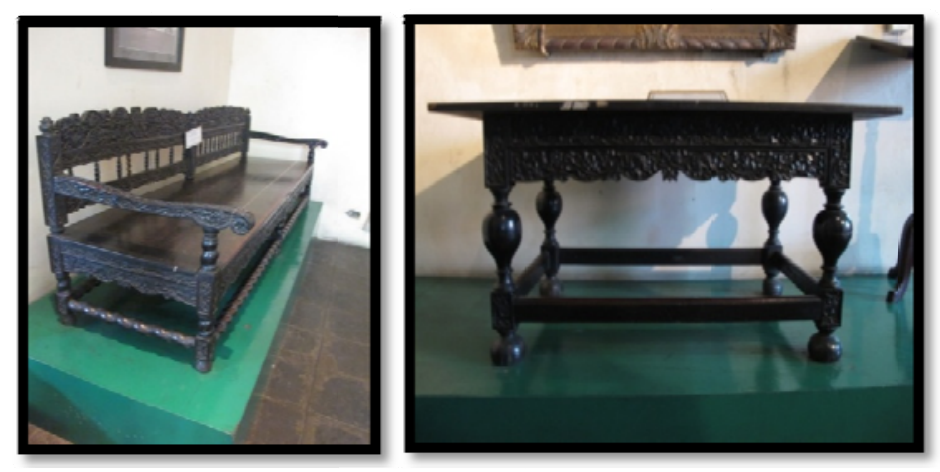

Gambar 12 Panggung sebagai Sarana Display 


\section{SIMPULAN}

Bangunan museum yang megah dan sebagai museum yang paling populer di kawasan Kotatua, Museum Sejarah Jakarta tidak pernah sepi akan pengunjung. Hal ini tentu merupakan satu nilai lebih yang harus terus dipertahankan bahkan ditingkatkan dengan melakukan penataan kembali melalui perawatan dan perlindungan terhadap koleksi mebel. Dalam upaya meningkatkan minat masyarakat untuk berkunjung ke Museum Sejarah Jakarta diperlukan penjelasan yang informatif mengenai koleksi mebel antik, pengaturan alur pengunjung museum, membuat alur cerita (storyboard) denan melakukan penataan yang kembali sehingga pengunjung dapat merasakan keterkaitannya dengan sejarah kota Jakarta dan memberikan perlindungan terhadap koleksi dengan meningkatkan keamanan terhadap koleksi sehingga pengunjung menghargai warisan sejarah budaya kota Jakarta. Pemanfaatan teknologi berupa audio visual dapat diterapkan untuk penyampaian informasi koleksi mebel antik dengan lebih atraktif dan informatif, misalnya kisah mengenai sejarah dan desain koleksi mebel antik Museum Sejarah Jakarta bahkan memberikan program menarik yang dapat disajikan khusus untuk anak-anak, dimana permainan dapat dibuat dengan melibatkan koleksi mebel antik sebagai petunjuk, sehingga anak-anak dapat menikmati koleksi mebel sejak dini.

\section{DAFTAR PUSTAKA}

Atterbury, P. (1997). De Geiluustreerde Antiek Encyclopedie. Amsterdam: Zuid Boekenprodukties.

Forrest, T. (1998). Antieke Mebelen. Amsterdam: Zuid Boekenprodukties. 